\title{
The Effectiveness of Traditional Games intervention program in the Improvement of Form One School-Age Children's Motor Skills Related Performance Components
}

\author{
MD. ALLI GIPIT CHARLES, MOHAMAD RAZALI ABDULLAH, RABIU MUAZU MUSA, NORLAILA \\ AZURA KOSNI, AHMAD BISYRI HUSIN MUSAWI MALIKI \\ Faculty of Applied Social Sciences, University Sultan Zainal Abidin, Terengganu, MALAYSIA, \\ Published online: August 25, 2017 \\ (Accepted for publication June 10, 2017) \\ DOI:10.7752/jpes.2017.s3141
}

\begin{abstract}
:
As children age, motor performance develops. Motor performance abilities enable children to process information in handling specific task efficiently. Although children develop motor skills in a variety of physical activities, it could be, however, easily achieved when they engage in voluntary activities in conformity with their interests. Traditional games offer the opportunity for children to play and officiate the rules without any constraint. The current study intends to explore the effectiveness of the traditional games intervention program in the improvement of form one school-age children's motor skills related performance components. A total number of 40 form one Malaysian student [male $(n=20)$ and female $(n=20)$ ] with age range of 12-13 selected randomly participated in the study. The quasi-experiment method was applied in the study and experiment group $(n=40)$ went through traditional games intervention which consisted of performing selected traditional games for 60 minutes, three times weekly for eight weeks. The pre-test (before treatment), mid-test (week fourth) and posttest (week eight) data were collected and analysed using MANOVA repeated measure. The results indicate a significant improvement of motor performance through traditional games intervention $[\mathrm{F}(8,29)=1704.16, p<$ $.05]$. Follow-up tests also show that the traditional games intervention is a factor $[\mathrm{F}(12,105)=1.99, p<.05]$ to agility $[\mathrm{F}(3,36)=.50, p>.05]$, reaction time $[\mathrm{F}(3,36)=.51, p>.05]$, speed $[\mathrm{F}(3,36)=3.64, p<.05]$ and balance $[\mathrm{F}(3,36)=.02, p>.05]$. There is sufficient evidence to conclude that Malaysian based traditional games are effective in improving motor abilities of school-age children.
\end{abstract}

Key Words: - Traditional games, Motor performance-related components, Form one school -age children, Quasi-experimental

\section{Introduction}

Physical capability is central to cognitive improvement during early adolescence. Montessori (1967) expressed that, for figuring out how to achieve its maximum capacity, it must be straightforwardly associated with physical development for the child. Motor skills are a crucial segment of development for all children. Gallahue (1993) explained that movement is at the extremely focus of adolescents' lives. It is an essential feature of all parts of their advancement, either in the motor, cognitive, or affective domains of human behaviour. It is, therefore, relevant to say that to deny youngsters the chance to receive the numerous rewards of standard, vivacious physical action is to deny them the chance to encounter the delight of productive development, the well-being impacts of development, and a lifetime as confident as well as competent movers. However, Piaget (1950) reported that from the primary days of life, children start utilising their bodies to find out about their general surroundings. At that age, they need physical activity to build strength, coordination, and confidence which will consequently lead them to lay the groundwork for a healthy lifestyle through gaining more control over how active they are. This can be achieved easily when the children are engaged in physical activities that are both stimulating and joyful.

Traditional games, also known as traditional sports, are hereditary heritage and played very often after harvest season usually by farmers (Addy Putra, Shahrul, Nor Ziratul \& Amirul, 2014; Ekunsanmi, 2012; Tatira, 2014). Traditional games were inherited from the older generation and passed on to the young generation through oral, sound or demonstrations. Traditional games have a racial and cultural value (Civarello, 2006) and were an integral part of the recreational activity (Addy Putra et al., 2014; Mohd. Salleh, 2005) perform for pleasure intent and serenity of mind (Ekunsanmi, 2012; Sahay, 2013).

Among the various types of traditional games played by the older generation in Malaysian perspective, were sepak bulu ayam, burung masuk sarang, gasing, marbles, petik mata, congkak, kite, batu seremban, buat rumah batu, galah panjang, tok harimau and tor duduk (Aziz \& Wan Ramli, 1994; Shafiee, 2008). These traditional games are played at no cost for buying any material because most of the materials can be obtained from the surroundings or recycled. For example, the batu seremban game uses only stones. In fact, among the traditional games, no materials are needed at all such as Tok Harimau, Tor Duduk and Tor Nusut (Aziz \& Wan Ramli, 1994). 
Although, a number of studies have been carried out and have proven that traditional games provide various benefits such as enhancing coarse and delicate motor skills (Akbari, Abdoli, Shafizadehkenari, Khalaji, Hajihosseini, \& Ziaee, 2009; Borhannudin, Saidon, Kok \& Bahaman, 2013) as well as improving cardiovascular health (Rauber, Boullosa, Carvalho, Moraes, Sousa, Simoes, \& Campbell, 2014), yet it is becoming more and more unpopular and less practiced by the younger generation these days. The reason partly, for the decreasing popularity of traditional games among the younger generation nowadays is the rapid industrial development, where the young people are more interested in watching television, playing electronic games i.e. video and computers, at home regardless of considering the time wasted (Akbari et al., 2009; Ekunsanmi, 2012).

Traditional games formerly were very popular and played in the evening by a wide range of ages (Ekunsanmi, 2012; Sahay, 2013) Nowadays; the younger generation more interested in indulging in a variety of high-tech toys like video games and computers as well as their habit of watching television more than the desire to play in sports (Addy Putra et al., 2014; Akbari et al., 2009; Ekunsanmi, 2012). A study conducted by Ekunsanmi (2012), reported that out of the $77 \%$ who used to play the traditional Yoruba game of Arin, only $18 \%$ are still practising it. This is due to lack of exposure to traditional games of the current generation of the importance of these traditional games to both their health and sporting abilities.

Determination of the types of motor fitness components built through this traditional game is important because the movement, concentration and adaptation in a skill can be developed through a wide range of traditional games (Lazar, 2005; Nyota \& Mapara, 2008; Piech \& Cieslinski, 2007; Rouhi, 2012; Sahay, 2013; Tatira, 2014). Thus, the study of the contribution of each type of traditional game of physical fitness in a particular motor fitness should be carried out to provide information to assisting stakeholders such as physical education teacher, coaches for improving healthy life and optimisation of sporting performance in a cost effective manner. Hence the purpose of the current study is to explore the effectiveness of the traditional games intervention program in the improvement of form one school-age children's motor skills related performance components.

\section{Materials and Methods}

Participants: 80 respondents (20 males and 20 females) was distributed to the experimental group according to the types of traditional games intervention programme with the same 5 number of people for each gender making it 10 people ( 5 men and 5 women) for each group.

Selected traditional games for the study

Among the types of traditional games selected by the researcher as intervention program are galah panjang, buat rumah batu, tok harimau and tor duduk. The galah panjang, also known as gelap cerah game, is a type of game that requires the player to cross the lines of an obstacle course that aims to test the skill of the player running past the obstacles. The Buat Rumah Batu or ketingting is a game where one throws a kor onto a partition and then hops onto each of the partitions with only one leg before retrieving the kor (Aziz Wan Ramli, 1994). Likewise, for Tor Duduk, which is also known as Acikai Duduk, and the Tok Harimau game aims to test the efficiency of the player to catch other players. The number of players in these games are not limited, that is, the more the players the more it could be enjoyed (Aziz \& Wan Ramli, 1994).

Data collection procedure

To measure motor performance, 30 feet shuttle run test, Nelson response test, 30-meter sprint test and Modified Bass test were selected. All measurements were taken at the beginning of the programme (pre-test), and the end of week 4 (mid-test) and 8 (post-test). The programme included an eight week period of selected traditional games. The length of each session was 60 minutes in three days a week and consisted of three parts whereas, warm-up, traditional games intervention programme and cooling down.

\section{Statistical Analysis}

In order to standardise each unit of motor fitness test, transformation process had been employed to convert raw scores of various units to a standard form of scores so that they are easy to be analysed as suggested by the previous researcher (Ahmad, 2003). Descriptive and inference statistics were performed using SPSS version 20 for windows. To organise and summarise classification of raw scores, descriptive statistics (mean and standard deviation, drawing tables) and the multivariate analysis of variance (MANOVA) repeated measure was used at a confidence level of $\mathrm{p} \leq 0.05$.

\section{Result}

Table 1: Descriptive statistics of achievements according to motor fitness component.

\begin{tabular}{lcrrrrrr}
\hline \multirow{2}{*}{ Component } & \multirow{2}{*}{} & \multicolumn{2}{c}{ Pre } & \multicolumn{2}{c}{ Mid } & \multicolumn{2}{c}{ Post } \\
\cline { 3 - 8 } & & $M$ & $S D$ & $M$ & $S D$ & $M$ & $S D$ \\
\hline Agility & 10 & 10.22 & 0.39 & 10.13 & 0.41 & 10.01 & 0.42 \\
Reaction time & 10 & 2.49 & 0.22 & 2.39 & 0.22 & 2.28 & 0.24 \\
Speed & 10 & 6.37 & 0.26 & 6.22 & 0.28 & 6.13 & 0.31 \\
Balance & 10 & 63.30 & 2.42 & 77.90 & 2.35 & 97.20 & 2.67 \\
\hline
\end{tabular}


Table 1 shows the descriptive statistics of raw data achievements according to motor performance in pre, mid and post-test. The mean, standard deviation and number of the parameters are shown.

Table 2: The MANOVA with repetitious measurement to determine the relation between motor fitness performance with the traditional games intervention programme.

\begin{tabular}{lcccccc}
\hline Effect & & Value & $F$ & Hypothesis $d f$ & Error df & $p$ \\
\hline Within Subjects & Pillai's Trace & .998 & $1704.158^{\mathrm{b}}$ & 8.000 & 29.000 & .000 \\
\hline
\end{tabular}

Table 2 projects the MANOVA analysis test. The Multivariate Pillai's trace indicates $\mathrm{F}(8,29)=1704.16, p<.05$ which revealed the significant relation between motor performance and traditional games intervention programme.

Table 3: The MANOVA with repetitious measurement to determine the effect of traditional game intervention programme with the motor performance.

\begin{tabular}{|c|c|c|c|c|c|c|c|}
\hline Effect & & & Value & $F$ & Hypothesis $d f$ & Error $d f$ & $p$ \\
\hline Between Subjects & group & Pillai's Trace & .556 & 1.99 & 12.000 & 105.00 & .032 \\
\hline
\end{tabular}

Table 3 shows the MANOVA analysis test. The Multivariate Pillai's trace $\mathrm{t}$ indicates $\mathrm{F}(12,105)=1.99, p<.05$ which revealed the effectiveness of traditional game intervention programme to the motor performance.

Table 4: Analysis Between-Subject Effects to determine the differentiate effect of each traditional game intervention on the agility component.

\begin{tabular}{lccccc}
\hline Source & Type III Sum of Squares & $d f$ & Mean Square & $F$ & $p$ \\
\hline Group & 153.99 & 3 & 51.33 & .495 & .688 \\
\hline Error & 3731.55 & 36 & 103.65 & & \\
\hline
\end{tabular}

Table 4 shows the analysis between-subject effect test to determine the differentiate effect of each traditional game intervention on the agility component. The result indicates $\mathrm{F}(3,36)=.50, p>.05$, which revealed that there is no different effect of each traditional game intervention on the agility component.

Table 5: Analysis Between-Subject Effects to determine the differentiate effect of each traditional game intervention on the reaction time component.

\begin{tabular}{lccccc}
\hline Source & Type III Sum of Squares & $d f$ & Mean Square & $F$ & $p$ \\
\hline Kumpulan & 156.29 & 3 & 52.09 & .508 & .680 \\
\hline Error & 3695.64 & 36 & 102.65 & & \\
\hline
\end{tabular}

Table 5 shows the analysis between-subject effect test to determine the differentiate effect of each traditional game intervention on the reaction time component. The result indicates $\mathrm{F}(3,36)=.51, p>.05$, which revealed that there is no different effect of each traditional game intervention on the reaction time component.

Table 6: Analysis Between-Subject Effects to determine the differentiate effect of each traditional game intervention on the speed component.

\begin{tabular}{lccccc}
\hline Source & Type III Sum of Squares & $d f$ & Mean Square & $F$ & $p$ \\
\hline Group & 899.47 & 3 & 299.82 & 3.64 & .022 \\
\hline Error & 2969.12 & 36 & 82.48 & & \\
\hline
\end{tabular}

Table 6 shows the analysis between-subject effect test to determine the differentiate effect of each traditional game intervention on the speed component. The result indicates $\mathrm{F}(3,36)=3.64, p<.05$, which revealed that there is a different effect of each traditional game intervention on the speed component.

Table 7: Analysis Between-Subject Effects to determine the differentiate effect of each traditional game intervention on the balance component.

\begin{tabular}{lccccc}
\hline Source & Type III Sum of Squares & $d f$ & Mean Square & $F$ & $p$ \\
\hline Group & 4.33 & 3 & 1.44 & .017 & .997 \\
\hline Error & 3074.46 & 36 & 85.40 & & \\
\hline
\end{tabular}


Table 7 shows the analysis between-subject effect test to determine the differentiate effect of each traditional game intervention on the balance component. The result indicates $\mathrm{F}(3,36)=.02, p>.05$, which revealed that there is a different effect of each traditional game intervention on the balance component.

Table 8: Descriptive statistics of the total different effect of motor performance from pre to post test of the traditional games intervention programme.

\begin{tabular}{llccc}
\hline \multirow{2}{*}{ Test } & Group & \multicolumn{3}{c}{ Different performance $(M)$} \\
\cline { 3 - 5 } & & pre-mid & mid-post & total \\
\hline 10 metres shuttle run & Tor duduk & 2.81 & 3.91 & 6.72 \\
Nelson response for leg & Galah panjang & 5.15 & 6.88 & 12.03 \\
30 metres sprint & Tok harimau & 4.75 & 6.46 & 11.20 \\
Modified Bass & Buat rumah batu & 57.24 & 86.26 & 143.50 \\
\hline
\end{tabular}

Table 8 shows the descriptive statistics of the total different effect of motor performance from pre to post test of the traditional games intervention programme. The result indicates that agility component contributed more by tor duduk, reaction time by galah panjang, speed by tok harimau, while balance by buat rumah batu.

\section{Discussion}

The overall results of the current study demonstrated that traditional game intervention programmes have a significant relationship with motor fitness performance among form one school age children (see Table 2). The results indicated that the traditional game intervention could be used to improve motor fitness performance i.e. fitness, speed, reaction time, speed and balance components. These findings support the findings of Rouhi (2012) and Pasand et al., (2014) on the effectiveness of the traditional games in enhancing agility, speed and balance.

Moreover, the results of the present study found that motor fitness performance increased among the intervention group in the fourth week of the mid-test. In fact, further improvement was observed through the eighth week of the post-test. This proves that the traditional game intervention program was highly effective to improve the motor fitness performance (agility, reaction time, speed and balance) among the children. The results of this study support the results of the findings carried out by Cheung and $\mathrm{Ng}$ (2003) where they found that the physical fitness level of 30 sampled adolescence of aged 14 years to 18 years have shown an increase in the fourth and eighth week through the use of circuit training method.

Our finding also found that traditional games intervention provided significant effects $(p<0.05)$ on the overall motor fitness performance of the children (see Table 3). This demonstrated that traditional games intervention is a factor to improving motor fitness performance. However, the results of the analysis found that traditional game interventions gave the same effect for agility, reaction time and balance component $(p>0.05)$. The reason being, the need for agility in all traditional games. During the game, the children strive to avoid being 'terminated' by the opposing side in a game of Galah Panjang, Tok Harimau and Tor Duduk, while Buat Rumah Batu game used agility to spin the body by changing the feet position in partitions 4 and 5 as well as 7 and 8 compartments. This finding is in concord with that of previous researchers who reported that agility could be affected by strength, speed, balance and coordination factors (Miller, 1998; Stafford-Brown et al., 2007) as well as skill (Cable, 1998). Similarly, Miller (1998), inferred that the achievement level for agility component is also influenced by breed factors and can be improved by adding the capability of strength, speed, balance and coordination either through teaching, training or practice drills (Ahmad, 2004).

Traditional games intervention program in our study also provides the same effects on the motor fitness performance in reaction time component (see Table 5). The reaction is considered faster in the study faster when one stimulation sign were received compared to multiple stimulations because then there would be many options for a response (Stafford-Brown et al., 2007). In traditional games, reaction time play a central role to escape from the control of or being caught by the opposing team in the traditional games of Galah Panjang, Tok Harimau and Tor Duduk. The players need to be agile, quick and balanced while producing relevant moves with environmental stimuli. Meanwhile, the reaction time in Buat Rumah Batu game is when the player drops and catches the Kor that was placed on the head before throwing the Kor to get a 'home'.

However, the researchers found that all traditional games intervention programs for Galah Panjang, Buat Rumah Batu, Tok Harimau and Tor Duduk yielded significantly different effects on the motor fitness performance for speed component (see Table 6). The differences were due to the differences in the aspects of the movement space size, for example, the field/court sizes of the Tok Harimau and Tor Duduk are wider compared to the size of the partitions of Galah Panjang and Buat Rumah Batu. The action of the player to avoid from 
being caught by the opposing side in the games of Tok harimau and Tor Duduk game is one of the requirements of speed in traditional games. The speed component is closely related to the strength component and is one of the important components in most games and sports, where this component is very important in events involving acceleration or keeping away from the opposing side (Ahmad, 2004).

The effectiveness of traditional games intervention program is also found to have significant effects on motor fitness performance for balance component (see Table 7). This is due to the balance component being affected by the efficiency of the visual information integration to the semi-circular vestibular system and muscle receptors (Stafford-Brown et al., 2007; Woollacott Shumway-Cook, 1990), as well as the strength of the legs (Ahmad (2004). For example, in the game of Buat Rumah Batu, the one-legged jumping action requires the strength of the leg to maintain balance while jumping to each of the following partitions. Therefore, the overall findings of this study support the findings of Clements et al. (2008), Eichberg (2005), Pasand et al. (2014), Rouhi (2012), Sahay (2013) and Tatira (2014), that traditional games contribute differently to physical fitness.

The total mean can identify the difference in contributions of the traditional game intervention program (Galah Panjang, Buat Rumah Batu, Tok Harimau and Tor Duduk) on the motor fitness performance (agility, reaction time, speed and balance) in all the three tests (pre to post test). The overall mean results show that intervention game for Tor Duduk provided the most performance improvement for agility component. The reason being in Tor Duduk, players have the opportunity to fake moves to avoid being 'touched' or 'terminated' by the opposing team player and the distance between opposing players are farther apart in comparison to other games such as Tok Harimau.

Galah Panjang provided the most motor fitness performance enhancement in reaction time. According to Baker et al. (2007), the reaction time is the time between the start of the movement and stimulation. Based on the observations made by the researchers during the study, it was found that in the Galah Panjang, many children applied the reaction time to respond every time an opponent player tried (stimulation) to touch opposing teams from crossing the line.

Based on the findings of the study, the researcher found that the Tok Harimau contributed to an increase in the motor fitness performance achievement in speed which is paramount. This could not be denied because of the wider Tok Harimau game space or court size and the need for the test samples to quickly escape from being caught by Tok Harimau and for Tok Harimau themselves to quickly turn and chase or pursue other players. Unlike Tor Duduk, although the size of the field for Tor Duduk is the same as that of Tok Harimau, due to the different way the games were played. Whereas, the players were already quite a distance away from the chasing opposing team player before the game even started as compared to the players in Tor Harimau game.

Balance plays a very important role in enabling execution of precise and exact movement in games and sports (Baker et al., 2007). The results of the study found that Buat Rumah Batu is the contributors to balance component performance improvement. Based on observation that was carried out, the researcher found that in the game of Buat Rumah Batu game, the body balance is very critical because the players have to maintain stability or body position to enable them to jump to each following partitions and the challenge in changing the Earth's gravity center position also the strength of the legs so as to enable them to jump one-legged throughout the game.

\section{Conclusion}

The present study revealed that traditional games intervention program which are Galah Panjang, Buat Rumah Batu, Tok Harimau and Tor Duduk, are very efficient in improving motor fitness performance, i.e., agility, reaction time, speed and balance. In fact, each traditional game intervention also showed differences in the effect of each component of motor fitness. Based on these results, it, therefore, recommended to coaches, physical education teachers and any physical fitness practitioner to apply these traditional games intervention programmes to increase their motor fitness performance. The tradition could also be revived by allowing children play every evening as it has been practised initially by the older generation.

Conflicts of interest - The authors have no conflicts of interest to declare.

\section{References}

Addy Putra M. Z., Shahrul Anuwar, M. Y., Nor Ziratul Aqma, \& Amirul Fahmi, R. (2014). Re-creation of Malaysian traditional game namely 'Baling Selipar': A critical review. International Journal of Science, Environment and Technology, 3(6),2084-2089.

Ahmad Hashim. (2003). Pengukuran kecergasan motor. Tanjong Malim: Quantum Books.

Ahmad Hashim. (2004). Pengukuran kecergasan motor. Tanjong Malim: Quantum Books.

Akbari, H., Abdoli, B., Shafizadehkenari, M., Khalaji, H., Hajihosseini, S., \& Ziaee, V. (2009). The effect of traditional games in fundamental motor skill development in 7-9 year old boys. Iranian Journal of Pediatrics, 19(2), 123-129.

Aziz Deraman \& Wan Ramli Wan Mohamad. (1994). Permainan tradisi orang melayu. Kuala Lumpur: Fazar Bakti Sdn. Bhd. 
Baker, R., Gledhill, A., Lydon, C., Miles, A., Mulligan, C., Saffery, G., Saipe, R., \& Sutton, L. (2007). BTEC national: Sport book 1 ( $2^{\text {nd }}$ ed.). England: Heinemann.

Borhannudin Abdullah, Saidon Amri, Kok Lian Yee, \& Bahaman Abu Samah. (2013). The impact of traditional games on the gross motor skill developmentof an early childhood. The Social Sciences, 8(6), 590-595.

Cable, T. (1998). Agility in football. Insight, 1, 42-43.

Cheung, C. Y. W., \& Ng, G. Y. F. (2003). An eight-week exercise programme improves physical fitness of sedentary female adolescents. Physiotherapy, 89(4), 249-255.

Civallero, E. (2007, August). Traditional games, music and oral tradition: Intangible tools in multicultural libraries. In IFLA Satellite Meeting 2007. Conference on Innovative Multicultural Library Services for All. Pretoria, South Africa (pp. 15-17).

Cleland, F. E., \& Gallahue, D. L. (1993). Young children's divergent movement ability. Perceptual and motor skills, 77(2), $535-544$

Clements, R., Mesangga, M., \& Millbank. A. M. (2008). Traditional children's games in Tanzania. Children, Youth and Environment, 18(2), 206-218.

Eichberg, H. (2005). Traditional games: A joker in modern development. Some experiences from Nodric countries and Nordic-African exchange. A paper for the international conference play the game, Copenhagen, November 2005.

Ekunsanmi, T. (2012). A note on the current status of Arin, a Yoruba traditional game played with the seeds of dioclea reflexa. Journal of Life Sciences, 6(3), 349-353.

Lazar, K. (2005). Why play and song? The role of folk games and folk songs in everyday life. Traditiones, 34(1), 191-197.

Miller, D. K. (1998). Measurement by the physical educator: Why and how. USA: Human Kinetics.

Mohd Salleh Aman. (2005). Asas pengurusan sukan. Kuala Lumpur: Universiti Malaya.

Montessori, M. (1967). The Absorbent Mind. 1949. Trans. Claude A. Claremont. New York: Del ta.

Nyota, S., \& Mapara, J. (2008). Shona traditional children's games and play: Songs as indigenous ways of knowing. The Journal of Pan African Studies, 2(4), 184-202.

Pasand, F., Ahmadian, M., Alsaadi, M. J., \& Bahramian, M. (2014). Impact of traditional exercises on perceptual-motor development in elementary school girl students. Indian Journal of Fundamental and Applied Life Sciences, 4(3), 1297-1302.

Piaget, J. (1950). Explanation in sociology. Sociological studies, 30-96.

Piech, K., \& Cieslinski, I. (2007). Traditional games and plays from southern Podlasie as an element of cultural heritage. Studies in Physical Culture and Tourism, 14(2), 149-158.

Rauber, S. B., Boullosa, D. A., Carvalho, F. O., De Moraes, J. F. V. N., De Sousa, L. R. C., Simoes, H. G., \& Campbell, C. S. G. (2014). Traditional games resulted in post-exercise hypotension and a lower cardiovascular response to the cold pressor test in healthy children. Frontiers in Physiology, 5.

Rouhi, M. (2012). Iranian traditional games pedagogy and their importance in improving physical and psychological aspects of elementary school students. Journal of American Science, 8(9).

Sahay, S. (2013). Traditional children's games of Bihar. Electronic Journal of Folklore. 54: 119-136.

Shafiee Ahmad Sulaiman Zakaria. (2008). Permainan tradisional di Malaysia. Kuala Lumpur: Must Sdn.Bhd.

Stafford-Brown, J., Rea, S., \& Chance, J. (2007). BTEC national in sport and exercise science. London: Hodder $\&$ Stoughton.

Tatira, L. (2014). Traditional games of Shona children. The Journal of Pan African Studies, 7(4), 156-175.

Woollacott, M., \& Shumway-Cook, A. (1990). Changes in posture control across the life span: A systems approach. Physical Therapy, 70(12), 799-807. 